\title{
Implementation of single-item alcohol screening and brief intervention in a primary care clinic in western Colorado
}

\author{
Kelly Marzano ${ }^{1 *}$, Carolyn Swenson ${ }^{2}$ \\ From INEBRIA 12th Congress, \\ Atlanta, GA, USA. 24-25 September 2015
}

\section{Background}

The U.S. Preventative Task Force recommends screening and brief intervention (SBI) as an effective strategy to address risky alcohol use [1]. Yet, only about $25 \%$ of binge drinkers have talked to a health care professional about alcohol use [2]. Perceived lack of time, difficulty implementing SBI protocols into clinic flow, and staff buy-in have been identified as barriers to successful implementation. We conducted a pilot study in a 3-physician primary care practice to evaluate successes and challenges in implementing a simple approach to alcohol SBI in primary care.

\section{Materials and methods}

A primary care clinic in Colorado implemented a singleitem alcohol screening question. Screening was only implemented for patients with certain appointment types (e.g., new patients, physical exams, visits for depression and anxiety). Patients who screened positive received a brief intervention provided by the physician. SBI data were documented in the electronic medical record. Patients scored positive when they indicated binge drinking in the past three months (more than 3/ occasion for women; more than 4/occasion for men). Physicians and staff participated in a site visit, staff focus group, and provider interviews.

\section{Results}

Of the 1190 patients with designated appointments types, only $53.8 \%(n=640)$ had a screening result recorded. Of appointments for which a response was recorded, $19.4 \%(\mathrm{n}=124)$ scored positive, and $47.6 \%$

\footnotetext{
* Correspondence: kmarzano@omni.org

'OMNI Institute, Denver, CO 80209, USA

Full list of author information is available at the end of the article
}

$(\mathrm{n}=59)$ of those with a positive screen received a brief intervention. In addition, $1.9 \%(n=10)$ of patients who scored negative were provided a brief intervention based on physician assessment of alcohol use. Staff identified that the screening question was easy to administer, and that it led to increased recognition among patients about level of alcohol consumption, and to improved care. Nonetheless, challenges in consistently adminstering the question and following up on positive screens, and in identifying appropriate resources for referrals, were noted.

\section{Conclusions}

Results suggest that there are benefits in implementing a single-item screening question for alcohol use. Nonetheless, challenges exist in consistently administering even a very simple SBI process in practice.

\section{Acknowledgements}

SBIRT Colorado is an initiative of the State of Colorado, Office of the Governor, and funded by the Substance Abuse and Mental Health Services Administration. It is implemented and managed by Peer Assistance Services, Inc., and administered by the Colorado Department of Human Services, Office of Behavioral Health. For more information, see http://www. improvinghealthcolorado.org.

\section{Authors' details \\ 'OMNI Institute, Denver, CO 80209, USA. ${ }^{2}$ Peer Assistance Services, Denver, CO, 80231, USA.}

Published: 24 September 2015

\section{References \\ 1. U.S. Preventative Task Force: Final update summary: Alcohol misuse: Screening and behaviroal counseling interventions in primary care [Internet]. Rockville (MD): U.S. Preventative Task Force; 2015, Available from: http://www.uspreventiveservicestaskforce.org/Page/Document/ UpdateSummaryFinal/alcohol-misuse-screening-and-behavioral-counseling- interventions-in-primary-care.}


2. Centers for Disease Control (U.S.): Most health care providers don't talk about alcohol, even when patients drink too much [Internet]. Centers for Disease Control (US); 2014, Available from: http://www.cdc.gov/media/ releases/2014/p0107-alcohol-screening.html.

doi:10.1186/1940-0640-10-S2-P8

Cite this article as: Marzano and Swenson: Implementation of single-

item alcohol screening and brief intervention in a primary care clinic in western Colorado. Addiction Science \& Clinical Practice 2015 10(Suppl 2):P8.

Submit your next manuscript to BioMed Central and take full advantage of:

- Convenient online submission

- Thorough peer review

- No space constraints or color figure charges

- Immediate publication on acceptance

- Inclusion in PubMed, CAS, Scopus and Google Scholar

- Research which is freely available for redistribution

Submit your manuscript at www.biomedcentral.com/submit 